\title{
Distribution of the coffee leaf miner, Leucoptera coffeella, and its parasitoids in the canopy of coffee, Coffea arabica in Puerto Rico'
}

\author{
Fernando Gallardo-Covas ${ }^{2}$
}

\begin{abstract}
An experiment was established in the summer of 1986 to study the distribution of the coffee leaf miner and its parasitoids within the coffee tree canopy. Mean estimates of percentage parasitization were 13.20, 14.32, and 16.00 at tree heights of $0-1,1-2$, and $2-3 \mathrm{~m}$, respectively. The experiment failed to show a significant difference befween parasitization of the coffee leaf miner at different levels in the canopy. Mined leaf index estimales of $0.7,0.7$ and 0.3 were obtained at $0.1,1-2$ and $2-3 \mathrm{~m}$, respectively. This experiment shows that $L$. coffeella acts at all levels in the tree canopy, although more so at lower levels.
\end{abstract}

\section{INTRODUCTION}

Leucoptera coffeella is the worst pest of coffee in Puerto Rico. If not controlled it can reduce photosynthetic activity by $50 \%$ and cause marked weight loss of trunk, branches (70\%) and roots $(60 \%)(1)$. In 1985 the coffee industry of Puerto Rico spent around $\$ 1$ million in its chemical control (2).

It seems necessary to evaluate other control methods, such as biological control, with less cost and environmental impact. Larvae and pupae of the coffee leaf miner are attacked by several eulophids and one braconid (Mirax insularis) $(4,5,7)$. $M$. insularis was introduced from Guadeloupe in 1937 and liberated at Quebradillas and Lares, where it became established at very low levels. The parasitoid complex controlled from 16 to $20 \%$ of the leaf miner larvae, a rate considered as very low (3). More information is needed from Puerto Rico to understand the bionomics of the parasitoids that attack the coffee leaf miner to see whether their effectiveness can be increased. One line of research in this direction is a study of the ecology of the parasitoids and their distribution within the coffee tree canopy.

Wankajala (6), in Kenya, studied the distribution of Leucoptera meyricki and its parasitoids within the coffee tree canopy. He established that $L$. meyricki infestations occurred at all heights, but parasitoids were

'Manuscript submitted to Editorial Board 6 May 1987.

"Assistant Entomologist, Department of Crop Protection, Adjuntas Substation, Agricultural Experimental Station, University of Puerto Rico. 
more abundant at two middle-heights $(1.5$ and $2.1 \mathrm{~m})$ than at the top or bottom levels of the tree.

The data presented are intended to prove or disprove that the low percentage parasitization may be attributed to a lack of synchronization between the activity of the coffee leaf miner within the coffee canopy and that of the parasitoids.

\section{MATERIALS AND METHODS}

A 10-year-old sunlight coffee grove (C. arabica var. Bourbon), was selected for this experiment at M. González's farm in Bo. Montes Llanos, Ponce, P. R. (650 m above sea level). This is an area where coffee groves have both high leaf miner and parasitization levels. No insecticide was used during the present study.

The survey started in May and ended in August 1986, in accordance with the peak of the coffee leaf miner population. Mined leaves were collected once a month at 3 height levels, 0-1, 1-2, and 2-3 m. A long wooden rod was used to mark the levels. Fifty mined leaves were randomly removed at each level in the coffee grove. Samples were taken to the laboratory, placed in a glass vial, stoppered with a cotton ball and observed for 1 month. The number of parasitoids and leaf miners was recorded.

The distribution of the coffee leaf miner within the coffee tree canopy was determined in 4 trees selected at random from the same coffee grove used for the study of the distribution of the parasitoids. Four branches per tree were selected at 3 height levels: 0-1, 1-2 and 2-3 m. Number of leaves and mines per branch were recorded monthly. The study started in May and ended in August 1986.

\section{RESULTS AND DISCUSSION}

Leaf mine index estimates of $0.7,0.7$ and 0.3 were found at $0-1,1-2$ and 2-3 $\mathrm{m}$ height, respectively. The experiment failed to show a significant difference between the leaf mine index and different levels in the tree canopy. Thus, the coffee leaf miner is active at all levels in the coffee tree, although heavier infestation was observed at lower levels as shown below.

\begin{tabular}{|c|c|c|}
\hline Levels ${ }^{3}$ & $\%$ Parasitism & Mine inde $x^{4}$ \\
\hline $0-1$ & 13.20 & .7871 \\
\hline $1-2$ & 14.32 & .7346 \\
\hline $2-3$ & 16.00 & .3880 \\
\hline
\end{tabular}

Table 1 presents the analysis between parasitoids and leaf mined index.

${ }^{3}$ Height in meters.

'Mine index $=$ mines per leaf. 
TABLE 1.- Summary of calculations of $F$-values for 1 ) Abundance of $L$. coffeella mines, and 2) Abundance of parasitoids in the tree canopy of C. arabica in Puerto Rico, 1986

\begin{tabular}{|c|c|c|c|c|}
\hline $\begin{array}{c}\text { Source } \\
\text { variation }\end{array}$ & $\begin{array}{c}\text { Sum of } \\
\text { squares }\end{array}$ & $\begin{array}{c}\text { Degrees of } \\
\text { fredom }\end{array}$ & $\begin{array}{c}\text { Mean } \\
\text { square }\end{array}$ & $\begin{array}{l}\text { Variance and } \\
\text { significance }\end{array}$ \\
\hline \multicolumn{5}{|l|}{ 1) } \\
\hline Between & & & & \\
\hline Levels & 0.28 & 2 & .14083 & .2545 \\
\hline Error & 3.32 & 6 & .55330 & \\
\hline \multicolumn{5}{|l|}{ 2) } \\
\hline Between & & & & \\
\hline Levels & 15.76 & 2 & 7.88 & .0729 \\
\hline Error & 648.54 & 6 & 108.09 & \\
\hline
\end{tabular}

The experiment failed to show a significant difference between percentage parasitization and different canopy levels. This finding indicates that parasitoid populations are uniformly acting over the whole population of the coffee leaf miner within the tree canopy. However, parasitization was most active on leaves at 2 to $3 \mathrm{~m}$ (fig. 1).

All 5 species of the Eulophidae parasitoid complex recorded from Puerto Rico (3) were observed. The braconid, Mirax insularis, the imported coffee leaf miner parasitoid, was observed during the survey period. It was more active at 1 to $2 \mathrm{~m}$ than at 0 to $1 \mathrm{~m}$ and 2 to $3 \mathrm{~m}$ (fig. 2).

Hyperparasitism is suspected among some species of the Eulophidae complex upon the braconid, $M$. insularis. This especially applies to Closterocerus sp., which is considered as a hyperparasite (6). Hyperparasites could determine the degree of parasitization of the coffee leaf miner by the imported coffee leaf miner parasitoid, $M$. insularis at the 0 to $1 \mathrm{~m}$ level (fig. 2). A more detailed study is needed to identify the hyperparasites of Mirax insularis and other primary eulophid parasitoids and their overall interaction.

\section{RESUMEN}

Distribución del minador, Leucoptera coffeella, y sus parasitoides en la fronda del cafeto en Puerto Rico

En el verano del 1986 se estudió la distribución del minador de las hojas del cafeto, Leucoptera coffeella, y sus parasitoides dentro de los límites de la copa del cafeto. Este experimento responde a la necesidad de entender la ecología del minador y sus parasitoides para poder aumentar el nivel de parasitismo.

Los porcentajes de parasitismo fueron 13.2, 14.3 y 16.0 a las alturas entre 0 y 1,1 y 2 , y 2 y $3 \mathrm{~m}$., respectivamente. No hubo diferencias significativas entre el porcentaje de parasitismo y las distintos alturas de la copa. Se encontraron todos los parasitoides del complejo eulófido hasta ahora informados en Puerto Rico y el parasitoide importado Mirox insularis 


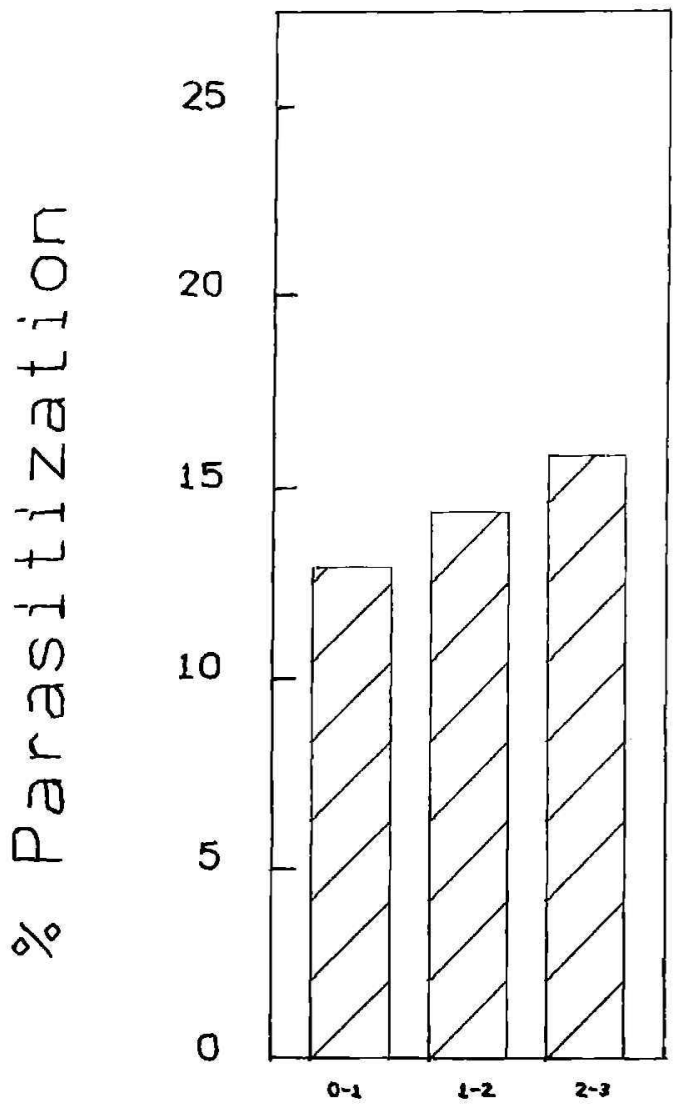

\section{Height Levels (meters)}

FIG. 1.-Parasitization percentage of the coffee leaf miner, L. coffeella, at three levels in the coffee tree canopy in Puerto Rico. 


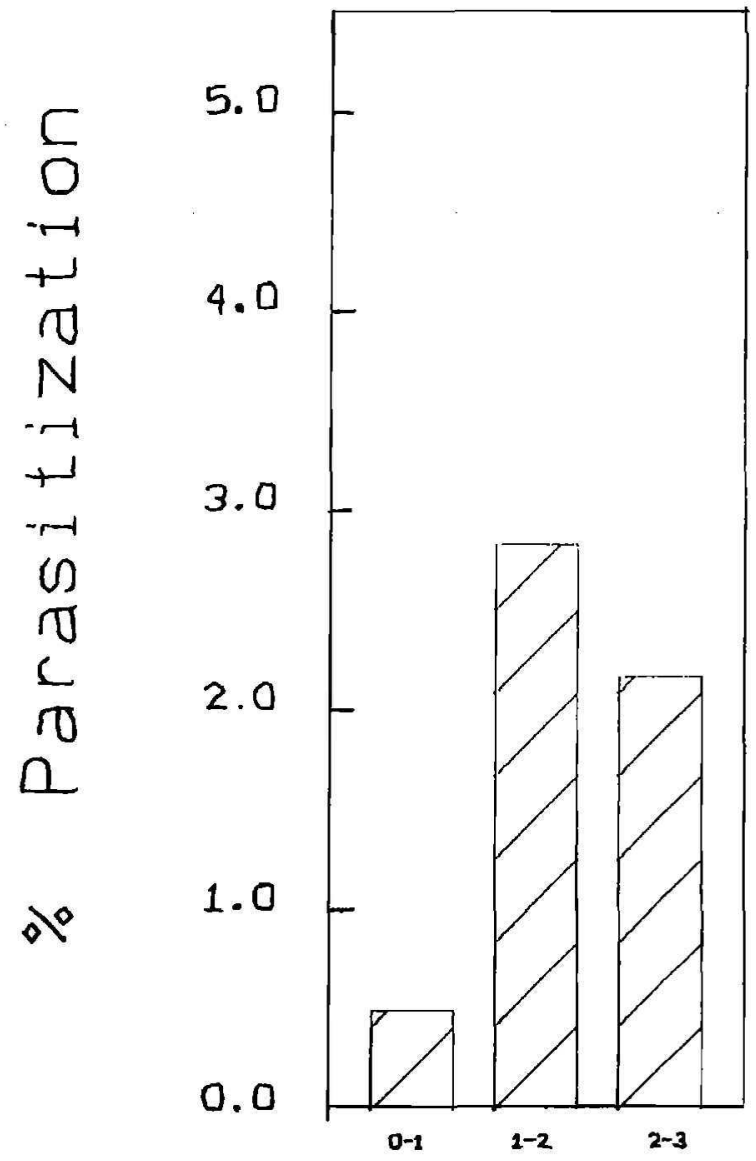

\section{Height Levels (meters)}

FiG, 2.-Parsitization percentage of the coffee leaf miner, $L$. coffeella by Mirax insularis at three levels in the coffee tree canopy in Puerto Rico. 
Muesebeck, el cual fue más activo en la búsqueda del huésped a la altura intermedia (1 y 2 metros).

Los promendios para el índice de galerías fueron $0.7,0.7$ y 0.3 a alturas entre 0 y 1, 1 y 2, y 2 y 3 metros, respectivamente. No se pudo comprobar si hay diferencias significativas entre el índice de galerías y a diversas alturas en la copa. Aunque no se pudieron observar diferencias significativas se observó una mayor incidencia del minador del cafeto en las ramas más bajas y a la altura intermedia $(0$ y 1 y 1 y $2 \mathrm{~m}$.). Se comprob que el minador de las hojas del cafefo está presente a todas las alfuras de la copa.

\section{LITERATURE CITED}

1. Cibes, H. R. and M. Pérez, 1958. Minador de la hoja disminuye en grado considerable el vigor de los cafetos. El café de FI Salvador, 28: 325-26.-

2. Deynes Soto, R, 1985. Informe econónico de la einpresa de café. Reunión de la Empresa del Café, Marzo, 18, Univ. P. R, Kecinto de Mayagüez, P. R.

3. Gallardo Covas, F., 1988. Faunal survey of the coffee leaf miner, Leucoptera coffeella, parasitoids in Puerto Rico. J. Agric. Univ. P. R. (In press).

4. Seín, F., 1940. Annu. Rep. P. R. Agric. Exp. Stn. 1938-39. pp. 50-52. Washington, D. C.

5. —, 1941-42. Annu. Rep. P. R. Agric. Exp. Stn, 1941-42, Washington, D. C.

6. Wanjala, F. M. E., 1978. Relative abundance and within canopy distribution of parasites of the coffee leaf miner, Leucoptera meyricki (Lep: Lyonetiidae) in Kenya. Entomophaga 23 (1): 57-62.

7. Wolcott, G. N., 1947. A quintaessence of sensitivity: The coffee leaf miner, J. Agric. Unin. P. R. 31 (3): 215-19. 